\title{
Moral Economy from Above and Below: Contesting Contraction of Migrant Rights in
}

\section{Austerity Britain}

\begin{abstract}
In 2010, Britain’s newly elected Coalition government ushered in a ‘moral mission’ of welfare reform. This paper considers its extension to the management of non-EEA migration and asylum, viewed here in the context of Fassin's conception of moral economy and related debate. The paper argues that the ensuing policy regime can be analysed as a moral economy 'from above', in terms of its underlying objectives and rationale, which is then challenged and contested 'from below' through the intervention of civic activists. Such contestation is framed in terms of a three-pronged critique of the welfare/migration complex, based on rationality, legality and morality, and examined in three key areas of welfare-related policy change - family life, maintenance provision for asylum seekers, and support for those without status. Policy in each area is considered alongside corresponding critique and with summary comment on key points for moral economy analysis. A fourth section sets these developments in the context of an emergent system of total control, and the conclusion reflects on broader implications for our understanding and usage of the notion of moral economy.
\end{abstract}

Key words: Moral economy, civic activism, welfare, migration, asylum.

\section{Introduction}

In 2010 Britain's newly elected Coalition government ushered in a 'moral mission' of welfare reform. This paper considers its extension to the management of non-EEA migration and asylum, viewed in the context of Fassin's $(2005,2009)$ conception of moral economy and related debate. It argues that the emergent welfare/migration complex in Britain can be 
viewed as a moral economy 'from above' in terms of its underlying objectives and rationale, and considers how far this is contested 'from below', by civic activists located in migrant advocacy groups. After discussion and refinement of the concept of moral economy, the paper examines three key areas of change - family life, welfare provision for asylum seekers, and support for those without status, alongside the form and content of critique. A further discussion sees these developments as part of an emergent system of total control, and a concluding section reflects on the implications for our understanding and usage of the notion of moral economy.

\section{Moral Economy and Migration}

A common starting point for contemporary interest in the concept of moral economy is E.P Thompson's (1971) reference to popular protest in $18^{\text {th }}$ century England, when working people were "inflamed to action" by rising prices. These protests were grounded in popular consensus on the norms and obligations shaping acceptable and unacceptable practices within the community of economic actors, giving crowd action a legitimising base in what Thompson terms a "moral economy of the poor". The notion has caught the attention of contemporary social scientists and gone through various adaptations in the process, but of particular interest for readers of this journal will be Fassin's (2005) appropriation of the term to analyse the tension between discourses of compassion and repression in the governance of immigration and asylum.

Fassin defines moral economy as "the production, distribution, circulation and use of emotions and values, and norms and obligations in social space” (Fassin 2009,18), and applies the term to the normative principles through which immigration and asylum are construed and acted upon in policy and practice. He pays particular attention to the "spaces of exception" that open up in the opposition between humanism and politics, and sees the moral economy of our times as stemming from a unique combination of the politics of order and the 
politics of suffering (Fassin 2005). In this context, he applies the idea of moral economy to humanitarian concessions that operate at the extreme margins of exclusion to address vulnerabilities often generated by the system itself. However, Fassin also argues more broadly for a need to grasp the "moral heart” of immigration and asylum policy (p366), asking what values and hierarchies of value are mobilised in a state's management of migration flows, and the attendant "war of words" (p378). Fassin (2012) therefore calls attention to the way that moral sentiments have become an essential force in contemporary discourse, and argues for an approach that can "seize morals at the point where they are articulated with politics” (p12).

His understanding of moral economy, however, pulls in two directions, potentially referring both to the value frame and classificatory devices that permeate the whole system of migration and asylum management, and to humanistic exceptions where "the tragedy of the modern condition can no longer be eluded” (Fassin 2012, 252). This incipient distinction is apparent in Fassin’s “Moral Economies Revisited” (2009) which ponders the opposite of Thompson's "moral economy of the poor" to observe that if it has one, it would be the moral economy of the masters. In revisiting the concept, he foregrounds the process of shaping moral sentiments, and broadens the remit of thinking on moral economy in a manner that chimes with arguments from Booth (1994) and others (Sayer 2007; Clarke and Newman 2012), to the effect that all economies are moral economies, in that all are supported by an underpinning value frame.

However, Fassin $(2009,18)$ goes further to note a shift of emphasis in recent debate, away from a traditional "moral economy" approach and towards an alternative "moral economy" approach, thus suggesting that economic primacy may be countered by moral principles. A focus on the production or evocation of moral sentiments can then support Fassin's (2009) further claim that moral economies are unstable and fluid realities, traversed by tensions and 
contradictions. This raises the possibility that such tensions will variously open up the field to claims, contestations, or full-blown moral challenge, and invites a further set of questions. If the system itself constitutes what might be termed a moral economy from above, we can consider both how far challenges engage an alternative moral vocabulary, and also whether the tensions and contradictions themselves open up avenues for claims and contestation that may take other forms.

\section{Conditionality and Rights}

While humanitarian exceptions can be seen as marking the limit of tolerable suffering, and may well engage an explicit moral imperative, Chauvin and Garces-Mascarenas (2012) argue that the moral economy pervading a whole system can in practice permit other modes of incorporation. They therefore note that though Fassin applies the term moral economy where a morality of compassion is overtly at stake, conditions and requirements throughout the system may amount to a moral economy geared rather to deservingness. Their focus is on undocumented migrants who can avail themselves of formal circuits of incorporation by furnishing proofs of presence, good conduct, and fiscal contribution, thus conforming to an over-arching value frame and emerging moral economy of desert. However, Chauvin and Garces-Mascarenas also find a degree of inconsistency whereby opportunities can arise from contradictions that are located within the law, and from tensions that run through policy, law and practice. Their observations thus point to a more far reaching moral economy that displays a nascent rationality through rules and conditions that permeate the whole system, but in a regime that itself may not be fully coherent. Such tension then raises broader questions as to how claims-making and contestation come about at systemic level, what form they take, and how far they effect change in the system itself.

These questions are advanced by Landolt and Goldring’s (2015) approach to the role of conditionality in "assembling” non-citizen status, which defines assemblage as a dynamic 
multi-scalar process constituted by social actors, power relations, discursive frames, regulatory systems, and bureaucratised administration. While not explicitly engaging the idea of a moral economy, they note that the assemblage of policies, regulations and procedures governing non-citizen presence may be embedded within a moral framework of desert that operates through a system of conditionality with respect to the terms of presence and access to rights. They also call for a systemic approach to analysing the production of multiple, connected, and changing categories of legal status, which recognises that the operation of the system itself may yield contradictions and inconsistencies, such that boundaries between statuses can be contested, breached, negotiated or otherwise altered over time.

Landolt and Goldring focus on the uneven experience of individual migrants as they negotiate such a system, and the "systemic contingencies" (p856) that often determine outcomes - imperfect knowledge, informal circulation of strategies, variable use of discretion, etc. However, they hope that an understanding of such non-citizen assemblage and the role of conditionality can inform more strategic intervention, and note that civil society action has sometimes run counter to restrictive trends. Such an endeavour must therefore look to the scope for varied forms of contestation beyond individual experience that may themselves be viewed as an assemblage of strategies, techniques and devices engaged by civic activists, but may then provide the grounds for a more systemic conception of an alternative moral stance.

These arguments call to mind Lockwood's (1996) notion of civic stratification, defined as a system of inequality shaping access to and enjoyment of the rights of citizenship, and extended by Morris (2002) to the elaboration of migrant statuses outside of citizenship. The role of formal statuses in governing entry to a territory and differential access to rights is now well recognised, but less attention has been paid to the informal dimension of Lockwood's model, and especially the role of moral resources in conferring advantages that include "the 
ability to attain one’s ends through the activation of shared moral sentiments” (p36). Lockwood argues that individuals or groups within the system can experience an expansion or contraction of rights according to constructions of their moral standing - as expressed in policy rationale, and in battles over desert that may be won or lost by civic activists. He notes that such activists make up a small minority of the general population, but that their significance should not be underestimated, and a ready connection can be made to advocacy groups operating within the immigration and asylum field.

\section{Research Question and Methods}

An emergent agenda thus directs attention to the functioning of a moral economy 'from above' - its dominant value frame, policy content, and forms of conditionality and control. More crucially for the present article, existing literature also points to tensions, inconsistencies and contradiction within law and policy that highlight the scope for intervention 'from below' by civic activists. We might therefore expect contestation to variously address the design of policy, the plausibility of its underlying assumptions, its coherence and consistency within an existing legal framework, and the question of how and where morality bites - all having implications for the moral standing of target groups. Within this framework, the present paper focuses specifically on welfare related issues in Britain as applied to non-EEA migration and asylum. It outlines key features of the regime established under “austerity” by the Coalition government (2010-15) and its Conservative successors (2015 ongoing), and considers three central policy areas - family life, welfare and asylum, and support for those without status - alongside the forms of contestation they have provoked. Further comment places these developments in the context of an emergent system of total control.

Various writers look to organisations located within civil society for creativity and challenge on pressing policy issues, and the present paper examines this potential through an analysis of 
critical responses to the contraction of rights in the policy areas identified. This exercise was based on a reading of some 150 items, such as newsletters, campaign documents, legal actions, and contributions to formal consultation by advocacy/activist groups that challenge key features of the emergent policy regime. Resultant critical commentary is not confined to the ideological level, and in addition to broad issues of principle it covers policy content and implementation, as well as legal contestability, to yield a continuum that runs from policy and practice, through law, to moral principles. Such contestation engages tension and contradiction within the system, which may be classified in terms of the internal coherence or rationality of policy aims, their consistency with pre-established obligations and hence their legality, and the nature of their legitimating values and hence their morality (cf. Morris 2016 on austerity). All are at issue in the construction of an alternative orientation, and point to an ongoing process of challenge that illuminates Fassin’s unstable and fluid realities.

\section{Austerity, Migration and Contestation.}

The announcement in Britain of a coming age of austerity (Cameron 2009) was followed by a proclaimed “moral mission” of welfare reform (Cameron 2012) and an attack on dependency culture in the name of fairness to hardworking taxpayers. This mission was extended to migration through the claim that breaking the "cycle of dependency" meant "sorting out welfare and immigration” (Cameron 2011), and a promise to reduce net migration from hundreds of thousands to tens of thousands ${ }^{1}$. Against a background drive for deficit reduction, migration was presented as both a source of domestic welfare dependency, and itself an additional drain on welfare resources. Despite official and other sources that undermine these claims (Migration Advisory Committee (MAC) 2014; Keen and Turner, 2016), the government position in effect both recognised and reinforced public concern over immigration, at a time when $77 \%$ of the population believed existing levels to be too high ${ }^{2}$. One prominent policy response was the fuller elaboration of an incremental system of control 
in which welfare provisions play a key role (Gower 2015), such that devices to minimise welfare inclusion also enhance opportunities for selection, monitoring, and deterrence. Within this process, rules of inclusion and exclusion governed by conditions of access and entitlement combine to shape both formal legal status and informal moral standing, and Forkert (2017) has noted their role in the management of public feeling. Though most overtly directed at EEA migrants (O’Brien 2015), the ensuing policy has had ramifications for third country nationals and asylum seekers, which are the focus of the present paper

Key devices with respect to non-EEA migrants have included income thresholds for entry and settlement - the latter conferring full welfare entitlement, but with qualifying yearly income set at $£ 35,000^{3}$. Such restrictions are challenged by evidence that migration contributes more to the economy than it takes out (Office of Budget Responsibility (OBR) 2013 Annex A), but other measures have raised rights-related issues that reach beyond economic calculation. Minimum income requirements have been established for family unification, there have been harsh cuts in levels of asylum support, and a tightening of access to maintenance for failed asylum seekers and other migrants without status. These measures have been introduced alongside an erosion of appeal rights ${ }^{4}$ for asylum support and immigration decisions, a prohibitively demanding definition of “exceptional circumstances”, and a reduction in the availability of legal aid. Such changes operate in the broader context of a "hostile environment" ${ }^{5}$ designed to make survival for undocumented migrants ever more difficult. The outcome is a stratified system of control that places limits and conditions on entry, erodes entitlement for those present, makes challenge more difficult the more marginal one's position, impugns the moral standing of migrants by assumptions of resource drain and/or abuse, and reduces the scope for compassion within the system.

The moral economy from above is therefore one of contribution, conditionality, deterrence and control. However, a total system requires a perfect mesh between ideological claims, 
legal framework, and policy design and execution, while cracks in the system will open up room for contestation, highlighting the tensions and contradictions noted by Fassin and others. Such challenge is documented below for the policy areas identified - family life, welfare and asylum, support for those without status, and the emergent system of total control. These areas have attracted strong engagement from civic activists, providing an interesting terrain for analysis within a moral economy frame, and though successes have been small in scale they are not negligible.

\section{Family Life}

\section{The Minimum Income Requirement}

Changes to the immigration rules effective from July 2012 (Gower 2014) introduced a minimum income requirement (MIR) of $£ 18,600$ for resident applicants (sponsors) seeking to bring an overseas partner (with additions for children), intended to reduce the burden on taxpayers and safeguard the economic interests of the country (Home Office (HO) 2012). The MIR chosen was one at which a family would not be eligible for income related benefits, and is significantly more demanding than the previous regime. ${ }^{6}$ This contraction is defended by the argument that incoming migrants must be able to integrate and that "family life must not be established in the UK at the taxpayer’s expense” (Gower 2014,17). The probationary period during which an incoming partner is denied access to public funds was accordingly increased from two to five years.

Critique by advocacy groups undermines the rationality of these rules in terms of their own objectives, (eg. Joint Council for the Welfare of Immigrants (JCWI) 2012; Liberty 20137) and has informed a critical review by the All Party Parliamentary Group (APPG 2013). This review questions the inflexibility of the rules in excluding additional income sources such as well evidenced third party support or the prospective earnings of an incoming partner, and for 
a "tick-box" approach valuing form over substance. JCWI (2012) sees the resultant impediments to family unification as contradicting official endorsements of the family as the bedrock of society (JCWI 2012), and notably 79\% of the sponsors affected are British citizens, who may as a result become exiled from their own country (Middlesex University/JCWI 2015). It is also argued that the rules in practice increase dependency on welfare benefits, by restricting the working hours of a sponsor parent due to child care responsibilities that an incoming partner could relieve, thus impeding their own integration.

A challenge to the legality of the rules culminated in a Supreme Court judgment ((MM and Ors [2017] UKSC 10), in which the Children's Commissioner and JCWI acted as formal interveners. Charges of discrimination by virtue of the impact on low paid groups and hence on ethnic minorities and women were dismissed by the appeal court as proportionate to the legitimate aims of the policy (MM v SSHD [2014] EWCA Civ 985, para 155). More telling was the claim that the rules failed to reflect obligations under the Convention on the Rights of the Child and S55 of 2009 Borders Citizenship and Immigration Act, which requires government policy to safeguard and promote the welfare of children in discharging its immigration functions. The Supreme Court found the rules to be unlawful in failing to give effect to these duties, a judgment given added force by a broader morality critique from the interveners.

One aim of this critique was to humanise debate by asking "how far the MIR promotes and protects family life, for individual human flourishing and society as a whole” (JCWI 2012,7). The minimum requirement was set with reference to economic factors, to the explicit exclusion of social and moral questions (Gower 2014,4), but the APPG expressed concern about unnecessary and unfair separation of families, and negative effects for children. Research conducted for the Children’s Commissioner (Middlesex University/JCWI 2015) graphically documents the resultant distress, with 15,000 children affected from 2012 to 
2015, and with ruptures nearing breakdown of the parental relationship. However, while the Supreme Court upheld the S55 challenge, its ruling also signalled the moral limitations of the law, and hence "the fact that a rule causes hardship to many, including some who are in no way to blame...does not mean that it is incompatible with Convention rights”8 (para 81). The government response to the Supreme Court ruling ${ }^{9}$ concedes some aspects of the rationality, legality and morality critiques, to yield a ten year (rather than five year) route to settlement. Where there could be “unjustifiably harsh consequences”, some flexibility is allowed and alternative sources of income can be considered in meeting the MIR. A further exception outside the rules - though “very rare indeed” (No Recourse to Public Funds (NRPF) 2018) - must be granted where a refusal would result in "unjustifiably harsh consequences”. However, guidance makes clear in both cases that unjustifiably harsh consequences will not generally follow where a couple "chose to commence their family life together whilst living in separate countries.” ${ }^{10}$ Responsibility and desert are therefore brought to bear and the scope for a positive decision on compassionate grounds is narrow in the extreme. (NRPF 2018,95) While Fassin’s finding that compassion and morality will often come into play at the margins of the system is thus born out, it was driven in the present case by action 'from below', albeit within tightly circumscribed limits.

\section{Zambrano Carers}

A family related benefit issue has also arisen in the context of EU law, with respect to those Third Country Nationals (TCN's) now known as Zambrano carers. The term refers to a Court of Justice case (C-34/09) in which refusal of a right of residence to a TCN whose minor age child held citizenship of the relevant Member State, was prohibited as depriving the child of the genuine enjoyment of its rights as an EU citizen. The court also ruled that Member States should where necessary make social assistance available, and in Britain this led to entitlement for mainstream benefits, until access was closed off by the 2012 Social Security Regulations 
(SI 2012/2587). In the absence of eligibility for these benefits, Zambrano families have had recourse to a lower level of support for a child in need via local authority provision under S17 of the Children Act (1989). The rationale for the policy - a reduction of "benefit tourism" - is summarised in a court statement from the Department for Work and Pensions (Sanneh v SSWP [2015] EWCA Civ 49 para 96). The measure is intended to remove the incentive for people coming to Britain to claim benefits, encourage those unlawfully present to regularise, and press TCN's wishing to have children here to ensure that they first have sufficient resources.

A challenge to exclusion from mainstream benefits was brought by the local authorities concerned, and when the case reached the Court of Appeal and later the Supreme Court, the AIRE Centre (for Advice on Individual Rights in Europe) became involved as an intervener. They advanced a number of issues as to the rationality of the policy - that the restriction on benefits bites only after the Zambrano situation has arisen (Sanneh v SSWP, para 97), so the deterrent effect is limited, and that once support has been recognised as crucial to the caring relationship, there is no basis for denying entitlement to mainstream benefits ${ }^{11}$. Furthermore, Lady Hale of the Supreme Court was “unconvinced” by official justifications (HC v SSWP [2017] UKSC 73, para 51), not least that of saving money by transferring costs from one arm of government to another. However, the legality argument was resolved in favour of the government - the court ruling that while the “effective citizenship” principle (article 20, Treaty on the Functioning of the European Union) required support in some form, the level of that support is governed by domestic not EU law.

The treatment of children in the case provoked further comment that goes beyond tightly framed arguments of legal purchase to enter the terrain of morality, most fully expressed by one of the judges. The case treats TCN's as the relevant comparator group for the denial of mainstream benefits, not other British children (para 40). Nevertheless, Lady Hale observes 
that this is not a case about adults' rights but children's rights, and specifically the rights of British children to remain living in their own society (para 39). She condemns the lack of consideration given to supporting these children, which falls by default onto the local authority, at a rate normally well below mainstream benefits levels. Implicitly raising a "fairness" issue, Lady Hale asserts that "these are British children, born and brought up here, who have the right to remain here all their lives" and notes "the impact on the proper development of these children of being denied a level of support equivalent to that of their peers.” (para 46) She finds the aim of strengthening immigration control to be "irrelevant to children who are not subject to it” (para 51), and though concurring in strictly legal terms that the appeal must be dismissed, she sends a strong moral message of dissent.

\section{Moral Economy from Above and Below}

Both the MIR and the exclusion of Zambrano carers from mainstream benefits have been driven by a moral economy from above, based on assumptions of resource drain or "benefit tourism” that justify moves to protect public resources and relieve the taxpayer burden, though a rationality critique has placed these claims in contention. In so far as moral questions of familial obligation and personal distress are addressed, this has been driven by international obligations that are written into domestic law. However, concessions on the MIR seem less the operation of compassion as against repression than reluctant measures that extend the conditionality regime to rigorous requirements for accessing established human rights, while Zambrano children continue to be held below the maintenance levels available to other citizen children. Though the assemblage of contestation in terms of rationality, legality and morality has had only limited practical effect, these three dimensions have combined to challenge dominant conceptions of desert and to reframe associated questions of moral standing, while placing limits on the extent of permitted exclusion.

\section{Asylum and Welfare}




\section{Asylum Support}

A contraction of welfare rights is also apparent in the case of asylum support, reduced in 1999 from $90 \%$ of standard welfare benefit levels (Income Support) to 70\%, on the assumption that higher rates were attracting "non-genuine” claims (Home Affairs Committee 2013). Payments had been uprated in line with mainstream benefits but the link was broken in 2008, while in 2011 the rates were frozen, given a stated need "to demonstrate fairness to the taxpayer”, (Refugee Action v SSHD [2014] EWHC 1033 (Admin), para 26) and a view that increased rates would “clog up the system” with spurious claims ${ }^{12}$. A later development in 2015 removed preferential rates for children and individual rates were thus standardised at $£ 36.62$ per week (a fall of $£ 16.34$ for under 16’s), with what was deemed a legitimate purpose of discouraging economic migration and protecting limited resources (Ghulam and Ors v SSHD [2016] EWHC 2639 (Admin), para 241).

The policy has been criticised on the grounds of rationality, and a Parliamentary Inquiry (2013) ${ }^{13}$ informed by advocacy groups found "no correlation between levels of support and numbers of asylum seekers in the UK”. The inquiry deemed rates too low for essential living needs, and viewed the assumption that worsening conditions would induce departure to be “dangerously flawed”. A legal challenge by Refugee Action (Refugee Action v SSHD [2014] EWHC 1033 (Admin)) had some success, with a ruling that the reduction of rates from what in 2007 had been regarded as a bare minimum required justification (para 130). The information used by the government was deemed inadequate to this task, and in particular a reduction for 16-18 year olds was found to be incompatible with S55 of the 2009 Act, (para 156) and the best interests of the child. The ruling, however, stopped short of moral judgment by requiring the government to recalculate, an exercise that in the event confirmed the frozen rates $^{14}$. A further challenge (Ghulam and Ors v SSHD [2016] EWHC 2639 (Admin)) to the 2015 reduction in children's rates was dismissed, the judge observing (para 313) that the 
court must not be drawn into micro-managing, and that beyond achieving the minimum standard required, the setting of rates was a matter for Parliament (para 290)

The limit of the law in these cases lies in evading substantive judgment by looking to a procedural solution in the setting of the rates. Advocacy organisations have in contrast argued the point in terms of morality, with Refugee Action seeing a reduction of the rates as “incompatible with a compassionate asylum system” ${ }^{15}$. In addition to legal argument regarding the Public Sector Equality Duty and the EU Reception Directive, they put forward evidence (paras132-3) pointing to regularly missed meals, the inability to purchase clothing and other essentials, and a failure to meet children’s basic needs (cf. Red Cross 2015). However, the procedural victory over the government ultimately failed to address these issues, and indeed was followed by a further reduction.

Minor age asylum seekers have also been a focus for public concern and civic mobilisation in relation to the "Dubs amendment" of the 2016 Immigration Act, designed to relocate unaccompanied asylum-seeking children from within Europe. The government did not commit to a stated number and fears of creating a "pull factor" led to narrow constraints in terms of age and date of arrival ${ }^{16}$. There has been widespread disappointment at the numbers accepted, which were determined by official calculations of available local authority placements, and advocacy groups questioned the rationale for the limit on the grounds that greater capacity existed. This led to an unsuccessful legal challenge (Help Refugees v SSHD [2017] EWHC 2727 (Admin)) that queried the procedure adopted for identifying places, though the moral case was made more fully elsewhere (ZAT and Ors v SSHD [2016] EWCA Civ 810) by graphic volunteer descriptions of the Calais jungle ${ }^{17}$ as a "living hell”. After further legal challenge on undue delay ${ }^{18}$, the government will now offer 'Calais leave' to a small number of minors with family ties in the UK but who did not qualify as refugees (Guardian, 14 $4^{\text {th }}$ September, 2018). 


\section{Section 4 support}

Resource contestation has also arisen in relation to further submissions from failed asylum seekers who remain present in Britain. Given child protection law, those with children have retained support until removal, under S95 of 1999 Act (see below for recent changes). Provision for those without children and who could not be removed was introduced under S4 of the 1999 Act, at a lower level and via a cashless 'azure card' system, to address concern about attracting non-genuine claims (Home Affairs Committee 2013).

Rationality arguments were again advanced against assumptions of a "pull factor" (Home Affairs Committee 2013), and a Parliamentary Inquiry (2013) called for the urgent abolition of S4 and implementation of a cash-based system. There was also concern about the high proportion of successful appeals against refusal, which then stood at 82\% (Home Affairs Committee 2013, para 81). However, a particular problem with S4 prompted activist intervention in relation to the exclusion from support of those making further submissions amounting to a fresh claim for asylum, until the claim had been validated as "fresh" intended to “discourage abuse of the system” (MK and AH v SSHD [2012] EWHC 1896 (Admin) para 123(48)). With waiting times for a decision commonly at four weeks or more (para 143), the rationality of the policy was called into question as a barrier to accessing asylum, and as creating destitution that has a wider impact on community cohesion, public health and crime ${ }^{19}$.

This argument provided the basis for a successful legal challenge to HO policy from the Migrant Law Project, with Refugee Action as intervener (MK and AH v SSHD [2012] EWHC 1896 (Admin)). Witness statements from a variety of organisations elaborated on the “hugely distressing” experiences of those denied support (para 176-80) and the judge deemed the further submissions policy unlawful. Destitution was seen as an inevitable consequence of the waiting time for support, creating an unacceptable risk of a breach of article 3 of the 
European Convention on Human Rights (ECHR) ${ }^{20}$ and an impediment to justice (para 184). Bringing together morality and legality, the judge therefore stressed that "there are human beings behind each application” who may be extremely vulnerable (para 183), and the right to a consideration of their case must be upheld (para 184), again raising an issue of fairness.

\section{Moral Economy from Above and Below}

The ongoing approach to asylum support has been based on a moral economy from above that erodes support in the name of deterrence and fairness to the taxpayer, thus harnessing deprivation as a means of control. The rationality of this policy has been repeatedly called into question, and there have been some small legal advances. However, the victory over the setting of rates was merely procedural and had no material effect, and though legal and moral obligations regarding the best interests of children have held failed asylum-seeking families within the support system, they have not prevailed against the erosion of child rates or the very limited implementation of the Dubs amendment. The S4 case on further submissions was therefore unusual in bringing morality and legality together to succeed by invoking fundamental rights of access to justice and protection from inhuman and degrading treatment, fairness and compassion thus prevailing against policy concerns.

\section{Failed Asylum Seekers and other 'Illegal' Migrants}

\section{Reforming the System}

Given this background, we should look at changes introduced by the 2016 Immigration Act, which among other things sets out measures for "reforming support for failed asylum seekers and other illegal migrants” (HO 2015). These were intended both to tighten access to HO support, and to curtail recourse to local authority provision under the Children Act. The rationale was that those who "make themselves destitute by refusing to leave" should not be entitled to maintenance. The move is intended to increase removals, on the grounds that 
“failed asylum seekers are illegal migrants and no more deserving of support than any other migrant in the UK unlawfully”. Plans therefore followed to curtail such support by abolishing S4 and limiting access to local authority provisions for children in need, and unaccompanied care leavers.

Formal consultation yielded mixed responses from individuals - some against support for the undocumented, and others concerned about child welfare and destitution - suggesting varied public views. Local authorities queried the implications for their own functions, and advocacy groups were found to be generally opposed to further restrictions (HO 2015, 3-4). The final proposals were to replace both S95 and S4 support for failed asylum seekers who are destitute with provision under a new S95A, with tighter conditions that shift the onus of proof on barriers to leaving from the HO to the applicant. Removal of a right of appeal against refusal of the new S95A was justified by the view that obstacles to departure raise “straightforward matters of fact” for which appeal rights are unnecessary (HO 2016). While these proposals do meet earlier calls to abolish S4 and replace it with cash-based provision at the same level as asylum support, the latter had already fallen to much the same level as S4. Crucially, the rationality of the policy has been questioned, and several organisations cite a pilot exercise in 2004, intended to enforce departure by the withdrawal of support, but in which only three families opted for voluntary return and almost one third (32) of the sample disappeared $^{21}$. The proposals rest on assumptions that behavioural change will mean fewer unfounded applications and greater compliance with departure. However, advocacy groups note that removing support will hinder the aim of managed engagement with voluntary return, ${ }^{22}$ and that loss of support will drive families underground ${ }^{23}$. The message is one of dehumanisation, desperation, and abandonment, in the face of which many will opt for destitution rather than return home ${ }^{24}$. Mayblin and James (2017) see destitution itself as a 
mark of policy failure - both of the support system, and of attempts to enforce departure whose costs fall heavily on third sector support organisations.

Though too early for legal challenges, there has been a legality critique of the proposals that rests in part on removal of a right of appeal against refusal of support - a loss of judicial oversight described as "preposterous" ${ }^{25}$ given the high proportion of decisions overturned ${ }^{26}$. Other criticism focuses on duties to children in need, and the Refugee Council ${ }^{27}$ note a "startling failure" to address the Convention on the Rights of the Child and duties under S55 of the 2009 Act. Several organisations note that a child remains in need under the terms of the Children Act even where a family could return but does not do so, and identify gaps in provision that would flow from the abolition of S4. Affected groups include destitute nonasylum seekers attempting to return or with further submissions outstanding, and unaccompanied asylum-seeking children with further submissions or who have absconded but seek to reinstate their claim.

Such criticisms prompted an extended definition of asylum to incorporate what would previously have been S4 cases awaiting a judicial review (JR) of their asylum application, or who had lodged further submissions, while a late amendment to the 2016 act created two new modes of provision removed from local authority powers, and with no right of appeal. 10A under Schedule 3 of the 2002 Nationality Immigration and Asylum Act provides a way back into support for families with further non-asylum submissions or appeals, those who are “appeal rights exhausted" but co-operating with return, and to secure the welfare of a child. 10B provides for destitute care leavers making a first application for leave, those who could bring or have a non-asylum immigration application or appeal, or those the local authority deems in need of support. However, the Immigration Law Practitioners Association (ILPA 2015) describes the result as "a series of tatty safety nets full of holes", in which the last 
resort is an appeal to local authorities who are left to manage the resultant destitution within their communities.

A critique in terms of morality argues that the whole policy is incompatible with human rights (ILPA 2015), and that statutory support should be available to all experiencing destitution (Red Cross 2015). It is also argued that the use of destitution to enforce departure is unacceptable in a civilised society, and that the new policy prioritises immigration control over the welfare of children. ${ }^{28}$ Advocacy groups highlight the need for an end to end process of support and a broader use of Discretionary Leave after a period in which return has not proved viable (eg. Red Cross 2017; Refugee Council $2015^{29}$ ). The overlapping aims of such interventions include a detailing of the human impact of destitution (Refugee Action 2017), calls for the restoration of human dignity (Red Cross 2015), and for a "kindling of moral responsibility towards those we exclude” (Jesuit Refugee Service 2018). Some see the need for a complete cultural shift within the HO, away from a culture of disbelief and towards a more positive approach to asylum casework as saving lives ${ }^{30}$. Others (Still Human Still Here 2015 ${ }^{31}$; cf Home Affairs Committee 2013) argue that greater investment in faster and more reliable decision making would increase the moral credibility of the system and encourage the compliance that the $\mathrm{HO}$ is seeking.

\section{Moral Economy from Above and Below}

Advocacy resistance forced some changes to the proposed measures to further restrict support for failed asylum seekers by pointing to the gaps that would be created, and a likely increased demand on local authority resources. Legal challenges may well follow as the changes unfold, especially regarding children's rights and the lack of appeal against denial of support. But perhaps the most forceful response thus far has been the argument that the changes go beyond what is morally acceptable, even given the primacy of control, and several groups put forward proposals for a more compassionate approach based on human dignity. Nonetheless, 
the changes now in place move inexorably towards ever harsher measures, in incremental steps towards a system of total control.

\section{Towards a Total System}

The measures documented above have narrowed the terms and conditions of entry and stay for TCN's and reduced asylum support, while also operating alongside an erosion of access to justice. Changes introduced via the Legal Aid, Sentencing and Punishment of Offenders (LASPO) Act of 2012 take most immigration and welfare issues out of publicly funded legal services. JR and asylum applications remain in scope, and after intensive lobbying ${ }^{32}$ so too does asylum support law in cases involving homelessness. The latter advance is partially reversed by the denial of a right of appeal against refusal of S95A, 10A or 10B support, though the Asylum Appeals Support Project (ASAP) has questioned the rationality of this policy, given the very poor quality of decision making on S95 and S4. ${ }^{33}$

While JR applications can still attract legal aid, secondary legislation under LASPO was to require 12 months lawful residence for eligibility, thus excluding (among others) failed asylum seekers and undocumented migrants. Re-running the moral economy of welfare contraction, this test was intended to limit legal aid to those with a strong connection to the UK (Joint Committee for Human Rights, 2014, para 1), to reduce costs, and secure "the best deal for the taxpayer” (Public Law Project v Lord Chancellor [2016] UKSC 39, para 14), given the government view that "we do not think that most immigration matters justify legal aid” (Gudanaviciene v Lord Chancellor [2014] EWCA Civ 1622, para 150). An activist challenge to the legality of the test was brought by the Public Law Project and upheld by the Supreme Court. The test was deemed unlawful in falling outside powers granted by the legislation and in excluding a group by virtue of personal circumstances or characteristics that bore no relation to the services in question (para 34). Fairness was again an issue, and a prior ruling ([2014] EWHC 2365 (Admin) para 77) saw the right to check whether decisions 
are correct as essential to upholding the rule of law as part of the grounding of a democratic society.

Nevertheless, a family unification sponsor falling foul of the MIR will not have access to legal aid, failed asylum seekers cannot appeal a refusal of support, and those with no further submissions but unwilling to leave are squeezed out of basic maintenance to become undocumented. Total exclusion is then secured by the policy launched in 2012 "to create here in Britain a really hostile environment for illegal migration.” The underpinning moral message is that “if you are here illegally, you shouldn't be entitled to receive the everyday benefits and services available to hard-working UK families and people who have come to this country legitimately to contribute.”34 It is now a criminal offence to work without permission, to employ some without permission to work, to drive while unlawfully present, or to rent property with cause to believe the tenant is unlawfully present ${ }^{35}$.

The measures have been criticised on rationality grounds, given the absence of any means to determine their effectiveness, the failure to understand their wider impact, and their discriminatory effects (Home Affairs Committee 2018; JCWI 2015). A legality critique attacks the lack of a remedy for wrongful decisions, the failure to accommodate the Public Sector Equality Duty (JCWI 2015), and the promotion of actions that would be defined as harassment under the 2010 Equality Act. ${ }^{36}$ A legal case against 'right to rent' checks is pending (Guardian June $7^{\text {th }}$, 2018). A morality critique condemns the measures for producing homelessness and destitution among vulnerable groups and creating a hostile environment for all migrants ${ }^{37}$.

In fact, the hostile environment policy was undermined by public exposure when those who arrived as children in the Windrush migration to Britain ${ }^{38}$ fell foul of residence requirements. Many suffered loss of work and/or benefits, and even deportation, if unable to prove their presence in Britain before January 1973, the date for removal of the right of abode for such 
migrants (Home Affairs Committee 2018). “Fairness” and “desert” were reconfigured to work in their favour (Observer, $20^{\text {th }}$ May, 2018), and some elements of the hostile environment have been paused, while the policy has been renamed "the compliant environment”. Meanwhile others are being driven away from emergency medical treatment to which they are entitled, facing barriers to education, and being rendered homeless by landlord checks (Guardian, August 1, 2018).

Yet the boundary marking legitimate presence is not clear cut, and a rationality critique ${ }^{39}$ shows how people can be administered into irregularity by erroneous decision-making, prohibitively high HO fees, and an absence of legal aid. The hostile environment has nonetheless sought to close the circle of incremental exclusions, and in 2012 the 14 year long presence route to settlement was replaced by a 20 year route followed by four further costly applications before settlement. ${ }^{40}$ Should an undocumented migrant be in a position to regularise through recourse to exceptional circumstances, issues of character or conduct, failure to comply with requirements, or owing a debt to the NHS may count against them ${ }^{41}$. Finally, the Court of Appeal has endorsed a restrictive approach to serious health conditions (GS (India) and Ors) v SSHD [2015] EWCA Civ 40) and stressed that there is no ECHR obligation to provide medical treatment unavailable in the home country. A stay of removal on article 3 grounds will therefore be granted only for death bed cases, curtailing a key instance of compassion in Fassin’s model. A Supreme Court ruling is awaited.

\section{Moral Economy from Above and Below}

This section has moved beyond the specific confines of welfare to address related rights to justice and survival. Critical comment has signalled the significance of a right to contest formal decisions as part of the functioning of democracy - though the judgment overturning the residence test for legal aid does not restore the broader cuts ${ }^{42}$. Yet a rationality critique notes the tenuous nature of the boundary between documented and undocumented presence, 
and the perverse effects that can follow from attempts to impose an environment of total control. The public sympathy generated by a failure of fairness in the treatment of Windrush cases is of particular interest, highlighting both fluidity in the system, and the significance of public engagement in cases of manifest injustice.

\section{Conclusion - Moral Economy Revisited}

Fassin's juxtaposition of compassion and repression in immigration law and practice is compelling, but the climate in Britain under the age of austerity points to an increasingly restrictive regime. The more the system becomes rule bound by conditionality, desert, and deterrence, and shielded from legal challenge, the more compassion is squeezed out of the formal system, such that it falls to advocacy organisations to make the moral case and to advance an alternative stance from below. There is therefore some advantage to refining Fassin's approach, which seems to locate compassion within the dominant system, albeit through its capacity to open up exceptions at the margins. For a fuller understanding we can

firstly examine the moral economy from above in shaping the contours of the formal system, and then consider where and how contestation arises. This adjustment permits more critical attention to the instability and fluidity Fassin identifies, which arises where tensions within the system create a space for contestation and for what he would term a "moral economy" from below.

The present paper has focused on the centrality of welfare issues in austerity Britain, and the moral economy from above operates through an ever more rule driven system, with conceptions of desert that have minimised the accommodation of compassion. We have seen how this is built into terms of entry in relation to family unification, maintenance levels for Zambrano carers, the management of asylum, and the treatment of those without status, all narrowing conceptions of legitimate presence. The related value frame erodes the moral standing of those subject to its operations by allegations of resource drain and/or abuse, 
which serves to justify a shrinking model of desert. However, such justification is susceptible to a rationality critique in terms of stated objectives, while legal battles emerge when policy collides with pre-existing legal obligations, and the rhetoric driving the system may be contested in terms of an alternative moral stance.

The scope for Fassin’s “moral economy” from below therefore rests on more than a simple opposition of compassion as against repression, and could be built around these three dimensions of challenge. The courts figure as the most effective avenue for achieving practical and immediate policy or procedural change, bringing to bear the force of law and holding governments to account in terms of pre-established legal commitments (eg. the Convention on the Rights of the Child, and articles 3 and 8 of the ECHR). There have been some successes, though cases also reveal considerable hesitation among judges when it comes to undermining the will of parliament. Judges may take the opportunity of a case to make a moral declaration (eg. the asylum support and Zambrano cases), but this does not necessarily shape the content of the judgment itself, except where the most fundamental rights are involved. Such rights prevailed on S4 support for pending fresh claims, while in other cases the treatment of children has marked the outer boundary of repression, albeit with only limited powers of constraint (eg. the MIR and Zambrano cases).

Conversely, contestation based on morality (eg. JCWI 2012; Jesuit Refugee Service 2018) may seek to engage public sympathy and provide a basis for Lockwood's “activation of shared moral sentiments”, but may struggle to dislodge the rhetoric from above (as with the Dubs amendment). The moral argument is often strengthened by a rationality critique that undermines the practical assertions supporting dominant rhetoric, as in claims of benefit tourism by Zambrano carers, or repeated references to a "pull factor" in relation to asylum support. Such critique can also have an impact on public perceptions, by grounding morality in concrete arguments that undermine a policy in more substantive terms, making its 
legitimacy more readily questionable, and possibly restoring the moral standing of some marginalised groups - as with the 'Windrush migrants'.

However, unless the dominant value frame can be more conclusively dislodged and replaced it seems that compassion will continue to be superseded by repression, while the erosion of publicly funded legal aid and the scaling back of appeal rights have made it increasingly difficult for individuals to challenge their treatment. Nevertheless, the three-pronged assemblage of civic activism documented in this paper has succeeded in opening up cracks in the system of control - be they rational, legal or moral - to maximise its inherent fluidity and instability, and to reveal its processual and changeable nature. Such critique has highlighted the contradictions and inconsistencies noted by Chauvin and Garcia-Macarenas (2012) and by Landolt and Goldring (2015), and led in some cases to a renegotiation of the boundaries at issue. Thus, in the absence of a perfect mesh between ideological claims, legal frames, and policy design and execution, lack of internal coherence within the system will continue to generate inconsistencies that invite and enable contestation. The role of advocacy organisations documented in the present study has been to identify and exploit these ongoing opportunities for challenge and change in a manner that questions the assumptions of a moral economy from above, to fuel the incremental advance of an alternative vision from below, through the accumulation of small successes and the articulation of a wider moral frame.

\footnotetext{
${ }^{1}$ https://www.telegraph.co.uk/news/politics/6961675/David-Cameron-net-immigration-willbe-capped-at-tens-of-thousands.html

${ }^{2}$ http://www.bsa.natcen.ac.uk/media/38108/immigration-bsa31.pdf

${ }^{3}$ Median income is $£ 27,195$.

${ }^{4}$ https://www.luqmanithompson.com/immigration-act-2014-part-2-appeals/
} 
${ }^{5}$ https://www.telegraph.co.uk/news/uknews/immigration/9291483/Theresa-May-interview$\underline{\text { Were-going-to-give-illegal-migrants-a-really-hostile-reception.html }}$

${ }^{6}$ Lesser requirements apply for sponsors on disability benefits.

${ }^{7}$ https://www.libertyhumanrights.org.uk/sites/default/files/changes-to-immigration-rulesbriefing-on-family-migration-inquiry-jan-2013.pdf

${ }^{8}$ Article 8, ECHR

${ }^{9}$ See https://www.freemovement.org.uk/home-office-makes-changes-appendix-fmminimum-income-rule-following-mm-case/

${ }^{10} \underline{\text { https://www.freemovement.org.uk/home-office-makes-changes-appendix-fm-minimum- }}$ income-rule-following-mm-case/

${ }^{11}$ Supplied by the Centre Director

12 http://www.bbc.co.uk/news/uk-26956544

${ }^{13}$ https://www.basw.co.uk/resources/report-parliamentary-inquiry-asylum-support-childrenand-young-people

${ }^{14}$ http://www.nrpfnetwork.org.uk/Documents/Home\%20Office\%20letter\%20asylum\%20supp ort\%20August\%202014.pdf

${ }^{15}$ https://migrantsrights.org.uk/blog/2018/01/23/support-asylum-seekers-trafficking-victimsstill-leaves-destitute/

${ }^{16}$ In Europe since 20.3.16, and under 15, or under 18 and accompanying a younger sibling.

${ }^{17}$ An camp for those seeking transit to Britain

${ }^{18}$ https://www.freemovement.org.uk/delay-of-21-months-in-child-refugee-case-foundunlawful/

${ }^{19}$ https://www.refugeecouncil.org.uk/assets/0001/6292/10_08_20_Advocacy_briefing_on_fur ther_subs_and_destitution.pdf

${ }^{20}$ Protection from inhuman and degrading treatment 
${ }^{21}$ Eg. https://refugeecouncil.org.uk/assets/0001/7040/Section9_report_Feb06.pdf

${ }^{22}$ http://www.asaproject.org/uploads/ASAP-Summary-A-Decade-of-disbelieving-destitution-

Oct-2015.pdf and https://stillhumanstillhere.files.wordpress.com/2009/01/response-to-the-

consultation-on-reforming-support-for-failed-asylum-seekers.pdf

${ }^{23}$ https://www.asaproject.org/uploads/ASAP-response-to-HO-Consultation-on-Asylum-

Support-7-9-15.pdf

${ }^{24} \underline{\text { https://stillhumanstillhere.files.wordpress.com/2009/01/response-to-the-consultation-on- }}$

reforming-support-for-failed-asylum-seekers.pdf

${ }^{25}$ https://www.refugeecouncil.org.uk/assets/0003/5789/Refugee_Council_response_to_asylu

$\underline{\text { m_support_consultation.pdf }}$

${ }^{26} \underline{\text { http://www.asaproject.org/uploads/ASAP-Summary-A-Decade-of-disbelieving-destitution- }}$

Oct-2015.pdf

${ }^{27}$ See 25

${ }^{28}$ https://www.childrenssociety.org.uk/sites/default/files/RCC_Schedule\%203WelfareofUnac companiedYoungPeople_HoCCS_Nov15_FINAL.pdf

${ }^{29}$ See 25

${ }^{30}$ http://www.asaproject.org/uploads/ASAP-response-to-HO-Consultation-on-Asylum-

Support-7-9-15.pdf

${ }^{31}$ See 24

32 http://www.asaproject.org/uploads/ASAP-response-to-Legal-Aid-consultation.pdf

${ }^{33}$ Ibid. 81\% of destitution appeals succeeded in 2011/12 and 68\% in 2015/16.

${ }^{34}$ https://www.gov.uk/government/publications/immigration-bill-2015-overarching-

documents/immigration-bill-201516-overview-factsheet

${ }^{35}$ https://www.freemovement.org.uk/hostile-environment-affect/

${ }^{36}$ Ibid. 
${ }^{37}$ https://www.migrantsrights.org.uk/wp-content/uploads/publications/MRN_briefingImmigration_Bill-House_of_Lords-Feb_2014.pdf

${ }^{38}$ The first Commonwealth arrivals travelled on MV Empire Windrush.

${ }^{39}$ See 34

${ }^{40}$ https://www.freemovement.org.uk/what-are-10-20-year-rules-on-long-residenceimmigration-rules-paragraph-276-continuous-lawful-residence/

${ }^{41}$ https://assets.publishing.service.gov.uk/government/uploads/system/uploads/attachment_dat a/file/653020/Chapter53_v16.pdf

${ }^{42}$ Now under review

\section{References}

APPG. 2013. Report of the Inquiry into New Family Migration Rules.

Booth, W. 1994. “On the idea of the moral economy.” American Political Science Review 88(3):653-67.

Cameron, D. 2009. http://conservative-speeches.sayit.mysociety.org/speech/601367

Cameron, D. 2011.

https://www.telegraph.co.uk/news/politics/conservative/8808521/Conservative-Partyconference-2011-David-Camerons-speech-in-full.html

Cameron, D. 2012. http://www.telegraph.co.uk/news/politics/conservative/9598534/David$\underline{\text { Camerons-Conservative-Party-Conference-speech-in-full.html }}$

Chauvin, S. and Garces-Mascarenas, B. 2012. “Beyond informal citizenship.” International Political Sociology 6(3): 241-59.

Clarke, J. and Newman, J. 2012. “The alchemy of austerity.” Critical Social Policy 32(3): 299-319 
Fassin, D. 2005. “Compassion and repression.” American Anthropological Association 20(3): 362-87.

Fassin, D. 2009. “Moral economies revisited.” Annales. Histoire, Sciences Sociales 64(6):1237-66.

Fassin, D. 2012. Humanitarian Reason. Berkley and LA: University of California Press. Forkert, K. 2017. Austerity as a Public Mood. Maryland: Rowman and Littlefield Gower, M. 2014. The Financial Requirement for Partner Visas. HC Library, SN/HA/06724. Gower, M. 2015. Immigration and Asylum: changes made by the Coalition Government 2010-15. HC Library, SN/HA/5829.

Home Office. 2012. “Changes to Family Migration Rules.” Impact Assessment. Home Office. 2015. Reforming Support for Failed Asylum Seekers and Other Illegal Migrants: Response to Consultation

Home Office. 2016. Reforming Support for Migrants without Immigration Status. Home Affairs Committee. 2013. Asylum, HC 71. Home Affairs Committee. 2018. The Windrush Generation. HC 990

ILPA. 2015. ILPA Briefing: Third reading of the Immigration Bill 2015.

JCWI. 2012. United by Love, Divided by Law. London: JCWI.

JCWI. 2015. No Passport Equals No Home. London: JCWI.

Jesuit Refugee Services. 2018. Out in the Cold. London: JRS.

Keen, R. and Turner, R. 2016. Statistics on Migrants and Benefits. London: House of Commons Library, BP 7445.

Landolt, P. and Goldring, L. 2015. “Assembling non-citizenship through the work of conditionality.” Citizenship Studies 19(8): 853-69.

Lockwood, D. 1996. 'Civic integration and class formation.' British Journal of Sociology 47(3): 531-50. 
MAC. 2014. Migrants in low-skilled work. London: Home Office

Mayblin, L. and P. James. 2017. Asylum and Refugee Support. Coventry: University of Warwick.

Middlesex University and JCWI. 2015. Family Friendly? London: Office of the Children’s Commissioner.

Morris, L. 2002. “Britain's immigration and asylum and regime.” Journal of Ethnic and Migration Studies 28(3): 409-25

Morris, L. 2016. “The moral economy of austerity.” British Journal of Sociology 67(1): 97117

NRPF. 2018. Assessing and Supporting Families who have NRPF. London: NRPF.

OBR. 2013. Fiscal Sustainability Report. London: HMSO

O’Brien, C. 2015. “The pillory, the precipice and the slippery slope.” Journal of Social Welfare and Family Law 37(1):111-36.

Parliamentary Inquiry. 2013. Report of the Parliamentary Inquiry into Asylum Support. Red Cross. 2015. Poor Health, No Wealth. London: Red Cross.

Red Cross. 2017. Can’t Stay, Can’t Go. London: Red Cross.

Refugee Action. 2017. Slipping Through the Cracks. London: Refugee Action.

Sayer, A. 2007. “Moral economy as critique.” New Political Economy 12(2): 261-270

Thompson, E.P. 1971. “The Moral Economy of the English Crowd” Past and Present 50

(Feb): 76-136 